\author{
Sedikova I. \\ Doctor of Economics, Associate Professor \\ Department of Management and Logistics \\ Odessa National Academy of Food Technologies \\ Kanatna str., 112, Odesa, Ukraine, 65039 \\ E-mail: irina-sedikova@ukr.net \\ ORCID ID: 0000-0003-4376-1267
}

\title{
DEVELOPMENT OF CONCEPTUAL PRINCIPLES OF THE CIRCULAR ECONOMY
}

High growth rates of natural resources consumption in recent years, pollution of the environment contribute to the development of theories regarding the future provision of natural resources on the Earth. The purpose of the article is to study the concept of sustainable development and the need for its introduction into economic activity, definition of ideas influencing the modern concept of the circular economy. The concept of stable development and circular economy is analyzed, common features and differences are defined. It has been established that the circular economy is a prerequisite and driver of the fourth industrial revolution. The basis of the circular economy are closed supply chains. They combine the usual processes of a direct supply chain with reverse logistics processes, ranging from product recovery, disassembly and reuse of individual parts.

Key words: reversive processes, management, sustainable development, circular economy.

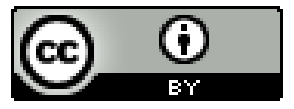

This work is licensed under a Creative Commons Attribution 4.0 International License http://creativecommons.org/licenses/by/4.0/
Statement of the problem and its connection with important scientific and practical tasks. High rates of natural resources consumption growth in recent years, pollution of the environment contribute to the development of theories on the future provision of natural resources of people on Earth. The constantly growing needs of the society do not correspond to the limited capabilities of the biosphere. The main natural resources are earth, air, oceans, rivers, lakes, underground waters, plants, animals, microorganisms, minerals. The level of resource consumption is unsustainable, both for the society and for business, which depend on consumption of natural resources under the current linear model of the economy. To achieve and maintain a balance in the ecosystem of the planet, the concept of sustainable development has been developed and actively promoted. The main condition for the achievement of sustainable development is the transition to the most responsible production and consumption - the circular economy.

The analysis of the latest publications on the problem. The concept of a circular economy is relatively new, the first time this concept occurs in the monograph by F. Claude and P. James. F. Dekker, G. Krotova, J. Kramer, J. Dajjan, L. Hunyan, L. Artemenko studied the problems of the circular economy of different countries. The works of K. Geyser, B. Danilishniy, L. Musina, T. Kwashi, D. Pudžari, S. Morha, K. Samersa are devoted to the influence of resource efficiency and resource conservation on economic development. The implementation of the circular economy in China was described by Peng, Chen, Van, Maine et al.
Forming of the aims of the research. The aim is to study the concept of sustainable development and the need for its introduction into economic activity, the definition of ideas that affect the modern concept of the circular economy.

The object of research is the processes of sustainable development and circular economy.

The subject of the study is theoretical and methodological, methodological and practical aspects of the use of circular business models and circular processes.

Giving an account of the main results and their substantiation. The most important global task of the present, in connection with the depletion of natural resources, global pollution of the environment is the achievement of sustainable development. Sustainable development is defined as "development that meets the needs of the present without undermining the ability of future generations to meet their own needs [1, p. 24], which includes three areas: economic, social and environmental.

The current socio-economic system is based on the linear economy, "take, make, dispose," the main element of creating value, which is the material flow, which includes only the primary material at the beginning of the value chain. This led to the fact that humanity today consumes 1.7 times more than the planet can generate. In the linear model, due attention is not paid to the environmental and social aspects, which are two of the three aspects of sustainability, in this regard, today's economy is not sustainable [2, p. 538]. Today there is an aggravation of world environmental problems, among them: reduction of 
biodiversity and pollution of the natural environment, in this connection there is a violation of natural balance. According to experts, since 1970, 50\% of the world's ocean flora and fauna has been destroyed [3]. The cause of pollution of the environment is to a large extent industrial production. The absence of environmentally-neutral technologies causes pollution of the atmosphere, reservoirs, and the growth of waste generation.

The indicator of atmospheric pollution is the growth of greenhouse gas emissions, and as a consequence, the global warming process [4]. To address this issue, today "green" technologies are actively developing, the main goal of which is to reduce greenhouse gas emissions and slow down the growth of temperature on the planet. The reason for pollution of water bodies and soils is the growing volume of garbage collection, as well as the lack of its proper disposal. This is due to the back side of progress. Every year, humanity throws 1,3 trillion tons of waste, most of which end their lives in the garbage dumps, which leads to poisoning the entire ecosystem [5]. According to the study, 14 billion tons of garbage annually enters the ocean, which has led to the creation of the "Great Pacific Garbage Spot" in the Pacific Ocean, consisting predominantly of plastic. [4]. In connection with

the emergence of acute global problems at the end of 1968, the Roman Club was created, which for the first time developed the concept of transition to global equilibrium [6].

The concepts of sustainable development and the circular economy are largely similar. Both concepts are global in nature, underline the importance of optimal integration of environmental and social aspects with economic progress, emphasize the obligations stipulated by environmental hazards, and emphasize the importance of increasing the participation of the authorities and the public. The main distinguishing features should be: firstly, the motives for sustainable development are based on past widespread traditions, while the motives of the circular economy are the emphasis on the fact that resources can be used in a more efficient way; secondly, sustainable development is aimed at benefiting the environment, the economy and society as a whole, while the main beneficiaries of the circular economy are economic entities that use this system. In the study of British and Dutch scientists M. Geissdoerfer, P. Savaget, N. Bocken, E. Hultink have been identifiend eight forms of the relationship of the circular economy and sustainable development (Table $1)$.

Table 1

Forms of the relationship of the circular economy and sustainable development*

\begin{tabular}{|l|l|l|l|}
\hline $\begin{array}{l}\text { 1. An indispensable con- } \\
\text { dition for the stability of } \\
\text { production, which leads to } \\
\text { improved economic and } \\
\text { environmental efficiency. }\end{array}$ & $\begin{array}{l}\text { 2. A prerequisite for sus- } \\
\text { taining economic growth in } \\
\text { a sustainable way, the exis- } \\
\text { tence of other means is not } \\
\text { excluded. }\end{array}$ & $\begin{array}{l}\text { 3. Mandatory, but not the } \\
\text { only, important condition } \\
\text { for the existence of stable } \\
\text { systems. }\end{array}$ & $\begin{array}{l}\text { 4. Opportunity for benefits } \\
\text { of various dimensions of } \\
\text { sustainable development } \\
\text { (resource efficiency, GDP } \\
\text { growth, job creation). }\end{array}$ \\
\hline $\begin{array}{l}\text { 5. One of several solu- } \\
\text { tions to support stable } \\
\text { systems. }\end{array}$ & $\begin{array}{l}\text { 6. The most stable concept } \\
\text { compared to any other. }\end{array}$ & $\begin{array}{l}\text { 7. This could potentially } \\
\text { lead to a negative effect } \\
\text { due to increased costs and } \\
\text { the inability to use circular } \\
\text { technologies. }\end{array}$ & $\begin{array}{l}\text { 8. This concerns the social } \\
\text { aspect of sustainable devel- } \\
\text { opment, that is why it's a } \\
\text { disadvantage. }\end{array}$ \\
\hline
\end{tabular}

* developed on the basis of [7, p. 757-768]

This list is not complete and does not seek to be exhaustive, as each type of relationship can be explored in more detail.

So we can conclude that the circular economy is an integral part of the ambitious concept of sustainable development and its task is to separate economic growth from consumption of natural resources. In parallel with this, the circular economy is a prerequisite and driver of the fourth industrial revolution [8, p. 66-70]. Achieving a sustainable balance of natural resources, optimizing consumption processes and preventing external negative effects can be achieved by increasing the availability of information through new digital technologies. The digital technologies, which are the result of the fourth industrial revolution, provide ample opportunities for collecting, processing of the received data, and further forecasting and developing recommendations for optimizing all economic processes and nature use, particularly through machine learning and artificial intelligence [9]. For the first time, the concept of a circular economy begins to appear in literature in the 1960 's. It is directly related to the transition from industrial to post-industrial (informational, digital) society and economics. Postindustrial society is characterized not only by the transition to the creation of services predominantly, but it is based on technical and technological progress, which allows modernization of forms and methods of production [10]. The development of innovative technologies in post-industrial society promotes a rapid improvement of production means, provides the opportunity to transition to a more resourceefficient economy. At the same time, due to the development of information technologies, an increase in the public's awareness of the external negative effects of production and consumption on the environment. Is observed an external negative effect occurs when the actions of one economic agent directly damage the environment of another agent. Two types: are distinguished from production and from consumption [11]. In this regard, the problem arises of finding an alternative way of allocating resources to achieve maximum efficiency for all agents by reducing the overall negative impact on the environment and setting a fair price for the actions of agents, taking into account their external negative effects. The most important stages in the development of the concept of circular economy are shown in Figure 1. 


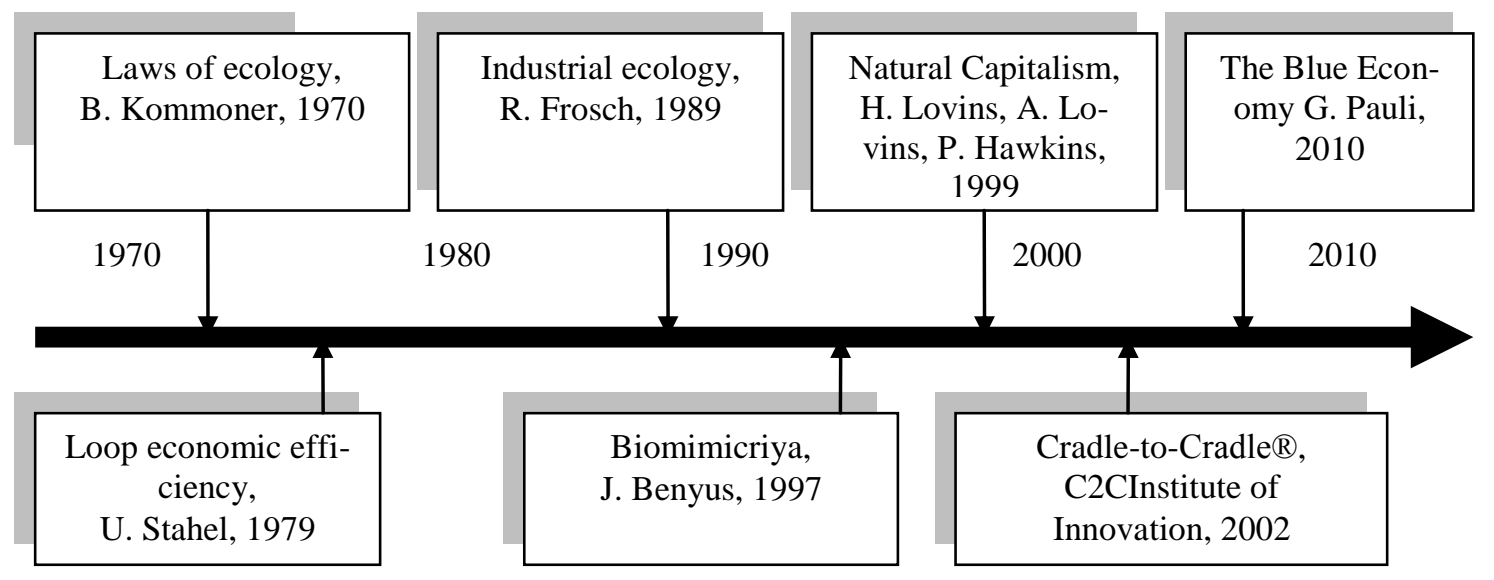

Fig. 1. Stages of development of the concept of circular economy*

* complied by the authors on the basis of $[7,17]$

The founder and president of the World Economic Forum in Geneva, K. Schwab argues that the main difference between the Fourth Industrial Revolution and all previous revolutions is the synthesis of technologies and their interaction in physical, digital and biological domains [12]. The main features of the Industry 4.0 are Internet things, robotics and artificial intelligence. To date, the research has shown that approximately $80 \%$ of human activity is conducted on the Internet $[13$, p. 50 52].

The digital economy implements complex radical innovations - food, process, marketing, organizational, social [14]. It creates a world in which virtual and physical systems of production flexibly interact with each other globally. According to the analysts, the transition to "Industry 4.0" will lead to increased energy efficiency and competitiveness of the economy, elimination of the boundaries between industries, and the reduction of technogenic influence on the environment [15]. There are more than ten visualizations of the circular economy model. However, the most widespread and complete model, as for the content in our opinion, is a model based on the development of E. MacArthur's fund.

According to this model, the circular economy should provide a phased reproduction, based on the nature of the principles of resource efficiency and waste lessness. To achieve this, there is a division into two types of closed cycles: biological and technical. The main condition for the existence and proper functioning of this system is not the confusion of two cycles in the process of circulation.

As part of the biological cycle, this scheme has the following chain: waste (non-toxic) after use fall back into the natural environment and become a nutrient medium for bacteria, with subsequent biological processes, they become a form of agricultural products.

The industrial cycle, which is formed through closed supply chains, is based on the following types of activities: maintenance (maintain / prolong), which consists in prolonging the life cycle of a product through maintaining its performance; Reuse / redistribute in primary or modified form; refurbish / remanufacture of components and / or components; recycle, waste recycling. There are three possible scenarios: up cycling (recycling to newer materials of higher quality), functional recycling (recovery of materials for the initial purpose, but not for the purpose of energy recovery) and down cycling (transformation into lower quality materials) [16, p. 244-269].

Important elements of the circular economy are:

1. Preservation and increase of natural capital by management of limited reserves.

2. Optimization of resource allocation through the circulation of products, components and materials with the highest utility throughout the time at all stages of the technical and biological cycle.

3. Promoting the development of system efficiency by identifying negative external factors and further redesigning of production activities [17].

The bases of the circular economy are closed supply chains. They combine the usual processes of a direct supply chain with reverse logistics processes, ranging from product recovery, remanufacturing, disassembly and reuse of individual parts. The ultimate goal is to preserve the value of consumed products in order to reduce the environmental impact on the entire supply chain [18]. In connection with the new approach to the conduct of economic activity, there is a need for innovation at all stages of the existence of products. For these purposes, it is necessary to apply new business models that are aimed at low consumption of materials and energy, and also have no negative external effects on the environment. The application of circular business models in various industries leads to significant environmental, socio-economic benefits. According to expert estimates, their introduction into automotive industry will create an opportunity to reduce consumption of raw materials by $98 \%$, provide energy savings by $83 \%$, reduce the cost of finished products to $40 \%$, and reduce carbon dioxide emissions to $87 \%$ [16]. For the functioning of the circular economy model, E. MacArthur's fund allocates the following groups of activities, which are important components of the transition to a circular economy. The main activities in the circular economy are shown in Table 2. 
Table 2

Types of activity in the circular economy*

\begin{tabular}{|l|l|l|}
\hline English name & Ukrainian name & \multicolumn{1}{|c|}{ Types of activity } \\
\hline Regenerate & Regenerate & $\begin{array}{l}\text { Nransition to renewable energy sources and materials. Restore, save the } \\
\text { health of ecosystems. Return the restored biological resources to the bios- } \\
\text { phere. }\end{array}$ \\
\hline Share & Sharing & $\begin{array}{l}\text { Shared use of assets (cars, rooms, appliances). Reuse Extension of service life } \\
\text { due to service, design, modernization, etc. }\end{array}$ \\
\hline Optimize & Optimize & $\begin{array}{l}\text { Improved productivity / product performance. Removal of waste in the pro- } \\
\text { duction and supply chain. Use of large databases, automation, remote sensing } \\
\text { and management. }\end{array}$ \\
\hline Loop & Create a loop & $\begin{array}{l}\text { Regeneration of products or components. Processing of materials. Extract } \\
\text { biochemical substances from organic waste. }\end{array}$ \\
\hline Exchange & Virtualize & $\begin{array}{l}\text { Dematerialization (books, CDs, DVDs). Dematerialization indirectly (online } \\
\text { stores). }\end{array}$ \\
\hline ReSOLVE & Decision & $\begin{array}{l}\text { Replacement of old non-renewable materials. Application of new technolo- } \\
\text { gies (3D printing). Choosing a new product / service (multimodal transport). }\end{array}$ \\
\hline
\end{tabular}

* developed on the basis of [17]

The use of these types of activities can be realized by the Industry 4.0, which contributes to more effective coordination of material and information flows. The key task in this process is to effectively generate, collect, process and provide information on the material content of each product, its use, location in the waste system [19]. Hereinafter we'll give examples of achievement of the stated goal:

1. Cyber-physical systems allow products to transmit information throughout the production process and the life cycle, including information related to the environment, material composition or environmental "footprint".

2. Reading (touch) devices allow you to collect, generate real-time data in «Industry 4.0». Ability to record detailed information about the location of waste, the exact composition of the material. These "fast data" are transferred to other companies that use them to plan production processes and adopt practical logistics solutions.

3. Correspondence of demand and supply of waste (secondary raw materials) can be realized by using Internet solutions. For these purposes, the use of automated market and logistics platforms is promising.

4. In a smart system of this kind, products that are ready for processing can automatically create their own Internet-based markets, implementing themselves on such platforms, based on the information about the content, possible uses.

5. Blockchain technology can be used to exchange information in an anonymous and encrypted form for the safety of patented production technologies.

The scientific literature also highlights the problems of the concept of a circular economy in terms of environmental sustainability. They consist of the following restrictions:

1. Thermodynamic limit (all processes obey the laws of physics; circular use itself does not provide environmental sustainability; contributions to circular projects require analysis in each case);

2. Spatial and temporal constraints of the system (accounting for the creation of both short-term and longterm environmental effects of circular activities, as well as analysis of the durability of long-term use of the product, and accounting for efficiency compared with future innovations);

3. Restrictions on physical economic growth (the physical scale of the global economy will continue to grow only over the next 50 years due to resource constraints);

4. Dependencies of the path and consolidation (circular processes represent a certain way of life of the product, which must compete with the traditional, as well as to consolidate in the future);

5. Intra-organizational against inter-state management strategies (waste utilization within industrial ecosystems and symbiosis);

6. Determination of physical flows (lack of statistics on circular materials, when the material is no longer needed and its value is negative, as a consequence there are difficulties in their administration, the definition of material flow is temporary spatial and cultural, therefore, it's necessary to use context) [20, p. 37-46].

Conclusions and prospects of the further investigations. An important issue that is today on the agenda of the world community is the separation of economic growth from the consumption of natural resources. This problem is caused by the rule of the linear model of economy and excessive consumption of natural resources, which is reflected in the increase in environmental problems, as well as in the resource crisis, which, according to some estimates, will come to 2050.

One way of solving this issue is to achieve sustainable development. Actions for its achievement are integrated in three directions: economic, social and environmental. An important condition for achieving sustainable development is the transition to a circular economy, consisting of phased reproduction of the very nature of the principles of resource efficiency and waste. Thus, it is opposed to a linear economy, the principle of which is "take, make, waste". The industry 4.0 and the increased availability of product information at every moment of time, thanks to digital technologies, play an important role in organizing a successful circular economy model.

This concept of the circular economy has been developing since 1970 . Today, it is actively promoting 
both by the states (China, the European Union) and numerous non-state foundations and institutions. It is a promising area of development, and can bring both economic benefits and benefits for the planet.

\section{References}

1. Razvitie i mezhdunarodnoe ekonomicheskoe sotrudnichestvo: Problemyi okruzhayuschey sredyi. Retrieved April 02, 2019, from http://www.un.org/ru/ga/pdf/brundtland.pdf

2. Pialot, O., Bisiaux, J., \& Millet, D. (2017). «Upgradable PSS»: Clarifying a new concept of sustainable consumption/production based on upgradablility. Journal of Cleaner Production, (4 (141)), 538-550. doi: 10.1016/j.jclepro.2016.08.161

3. Our seas are being decreased, fish are dying - but humanity is threatened too. (2015). Retrieved April 02, 2019, from https://www.theguardian.com/environment/2015/sep/20/fish-are-dying-but-human-life-is-threatened-too

4. 4Ocean Team. How Much Trash Is In Our Ocean? (2017). Retrieved April 8, 2019, from https://4ocean.com/blogs/blog/how-much-trash-is-in-our-ocean

5. World Bank. Knowledge Papers: Urban Development Series. Chapter 3: Waste Generation. (2016). Retrieved April 07, 2019, from http://siteresources.worldbank.org/Resources/336387/Chap3.pdf

6. Kumar, S. (2016). Millennium Development Goals (MDGs) to Sustainable Development Goals (SDGs): Addressing Unfinished Agenda and Strengthening Sustainable Development and Partnership. Indian Journal of Community Medicine, 1(41), 1-4. doi: 10.4103/0970-0218.170955

7. Geissdoerfer, M. (2017). The Circular Economy - A new sustainability paradigm? Journal of Cleaner Production, 4(143), 757-768. doi: 10.1016/j.jclepro.2016.12.048

8. Pakhomova, N. V., Richter, K. K., \& Vetrova, M. A. (2017). Circular Economy as Challenge to the Fourth Industrial Revolution. Innovatsii, 7(225), 66-70.

$\begin{array}{lllllll}\text { 9.Wupperinst.org. } & \text { (2017). } & \text { Retrieved } & \text { April } & 5, & 2019, & \text { from }\end{array}$ https://wupperinst.org/fa/redaktion/publications/In_Brief_2017-4_en.pdf.

10. Savina, I. V. (2017). Postindustrialna ekonomika yak ekonomichna katehoriia, etapy stanovlennia ta rushiini syly. Visn. Ternopilskoho Nats. Un-tu, ekonomichni nauky, 1-34.

11. Varian, H. (1992). Microeconomic Analysis. N-Y: WW Norton.

12. Shvab, K. (2017). Chetvertaya promyishlennaya revolyutsiya. Moscow: Eksmo.

13. Pister, E. I., Daynichenko, A. V., \& Shestakova, A. V. (2018). Chetvertaya promyishlennaya revolyutsiya: Megatrendyi. In Innovatsionnoe razvitie: Potentsial nauki i sovremennogo obrazovaniya (pp. 50-61). SPb.: «Nauka i Prosveschenie».

14. Rykhter, K. (2017). Tsyfrova ekonomika - innovatsiia 21 st: Vyklyky stiikoho rozvytku. In Innovatsiiinyi rozvytok: Potentsial nauky ta suchasnoi osvity (pp. 48-50). Kyiv: «Osvita 21 st.».

15. Industriia 4.0: Chetverta promyslova revoliutsiia yak stymul hlobalnoi konkurentospromozhnosti. (2017). Retrieved April 05, 2019, from http://pmef-2017/articles/4277607

16. Pahomova, N. V., \& Vetrova, M. A. (2017). Perehod k tsirkulyarnoy ekonomike i zamknutyim tsepyam postavok kak faktor ustoychivogo razvitiya. Vest. SPb Un-ta, 3(2), 5. ekonomika, 244-267.

17. Macarthur, E. O. (2015). Ellen MacArthur Foundation: Towards a Circular Economy: Business Rationale For An Accelerated Transition. Retrieved April 06, 2019, from https://www.ellenmacarthurfoundation.org/downloads/Foundation-9-Dec-2015.pdf

18. Battin, D. (2017). Closed Loop Supply Chain (CLSC): Economics, Modeling, Management and Control. International Journal of Production Economics, 2(183), 321-329. doi: 10.1016/j.ijpe.2016.11.020

19. Wilts, H. (2017). The digital circular economy: Can the digital transformation pave the way for resourceefficient materials cycles? Berlin: Wuppertal Institut für Klima, Umwelt, Energie gGmbH. doi: 10.19080/IJESNR.2017.07.555725

20. Korhonen, J. (2018). Circular Economy: The Concept and its Limitations. Ecological Economics,21(143), 37-46. doi: 10.1016/j.ecolecon.2017.06.041

Received 15 April 2019

Approved 29 April 2019

Седикова И.А. Available in Internet 5.07.2019

доктор экономических наук, доцент кафедра менеджмента и логистики Одесская национальная академия пищевых технологий ул. Канатная, 112, г. Одесса, Украина, 65039 E-mail: irina-sedikova@ukr.net ORCID ID: 0000-0003-4376-1267

\section{УПРАВЛЕНИЕ РЕВЕРСИВНЫМИ ПРОЦЕССАМИ ПРЕДПРИЯТИЙ В ЦИРКУЛЯРНОЙ ЭКОНОМИКЕ}

Высокие темпы прироста потребления природных ресурсов в последние годы, загрязнение окружающей среды способствуют развитию теорий относительно будущего обеспечения природными ресурсами людей на Земле. Главным условием достижения устойчивого развития является переход к 
более ответственному производству и потреблению - циркулярной экономики. Целью статьи является исследование процессов устойчивого развития и необходимости ее внедрения в экономическую деятельность, определение идей, влияющих на современную концепцию циркулярной экономики.

Понятия устойчивого развития и циркулярной экономики во многом похожи. Главными отличиями являются, во-первых, мотивы устойчивого развития основаны на прошлых распространенных традициях, в то время как мотивам циркулярной экономики является упор на то, что ресурсы могут быть использованы более эффективным способом. Во-вторых, устойчивое развитие нацелено на то, чтобы принести пользу окружающей среде, экономике и обществу в целом, в то время как основные бенефициары циркулярной экономики - это экономические субъекты, применяющие эту систему.

Можем сделать вывод что, циркулярная экономика - это неотъемлемая часть амбициозной концепции устойчивого развития ее задачей является отделение экономического роста от потребления природных ресурсов. Параллельно с этим, циркулярная экономика является предпосылкой и драйвером четвертой промышленной революции. Цифровые технологии, которые являются результатом четвертой промышленной революции, предоставляют широкие возможности для сбора, обработки полученных данных. Цифровая экономика создает мир, в котором виртуальные и физические системы производства гибко взаимодействуют между собой на глобальном уровне.

Согласно этой модели, циркулярная экономика должна обеспечивать поэтапное воспроизведение, основой которой являются принципы ресурсной эффеективности и безотходности. Для достижения этого происходит разделение на два вида замкнутых циклов: биологический и технический. Главным условием существования и правильного функционирования данной системы является не смешиваемость двух циклов в процессе циркуляции.

Основу циркулярной экономики образуют замкнутые цепи поставок. Они объединяют обычные процессы прямой цепи поставок с обратными логистическими процессами, варьирующиеся от восстановления продукта, ремануфактуринга, разборки и повторного использования отдельных частей.

Применение данных видов деятельности может быть реализовано благодаря Индустрии 4.0, способствующей более эффеективной координации материальных и информационных потоков. Ключевой задачей в этом процессе является эффективное генерирования, сбор, обработка и предоставление информации о материальном содержании каждого продукта, его использовании, местонахождении в системе отходов.

Ключевые слова: реверсивные процессы, управление, устойчивое развитие, циркулярная экономика.

Седікова I.O.

доктор економічних наук, доцент

кафедра менеджменту та логістики

Одеська національна академія харчових технологій

вул. Канатна, 112, м. Одеса, Україна, 65039

E-mail: irina-sedikova@ukr.net

ORCID ID: 0000-0003-4376-1267

\section{УПРАВЛІННЯ РЕВЕРСИВНИМИ ПРОЦЕСАМИ ПІДПРИЄМСТВ В ЦИРКУЛЯРНІЙ ЕКОНОМІЦІ}

Високі темпи приросту споживання природних ресурсів за останні роки, забруднення навколишнього природного середовища сприяють розвитку теорій щодо майбутнього забезпечення природними ресурсами людей на Землі. Головною умовою досягнення сталого розвитку є перехід до найбільш відповідального виробництва і споживання - циркулярної економіки. Метою статті є дослідження концепції сталого розвитку та необхідності її впровадження в економічну діяльність, визначення ідей, що впливають на сучасну концепцію циркулярної економіки.

Поняття стійкого розвитку і циркулярної економіки багато в чому схожі. Головними відмінностями є, по-перше, мотиви сталого розвитку засновані на минулих поширених традиціях, в той час як мотивами циркулярної економіки $є$ наголос на то, що ресурси можуть бути використані більш ефективним способом. По-друге, сталий розвиток націлений на те, щоб принести користь навколишньому середовищу, економіці та суспільству в цілому, в той час як основні бенефіціари циркулярною економіки - це економічні суб'єкти, які застосовують цю систему.

Отже можемо зробити висновок що, циркулярна економіка - це невід'ємна частина амбітної концепції сталого розвитку її завданням $є$ відділення економічного зростання від споживання природних ресурсів. Паралельно з цим, циркулярна економіка $є$ передумовою і драйвером четвертої промислової революції. Цифрові технології, які $є$ результатом четвертої промислової революції, надають широкі можливості для збору, обробки отриманих даних.

Цифрова економіка створює світ, в якому віртуальні та фрізичні системи виробництва гнучко взаємодіють між собою на глобальному рівні.

Відповідно до цієї моделі, циркулярна економіка повинна забезпечувати поетапне відтворення, основою якої є природі принципів ресурсної ефективності та безвідходності. Для досягнення цього відбувається поділ на два види замкнутих циклів: біологічний і технічний. Головною умовою існування та правильного функціонування даної системи $є$ не змішуваність двох циклів в процесі циркуляції. 
Основу циркулярної економіки утворюють замкнуті ланцюги поставок. Вони об'єднують звичайні процеси прямого ланцюга поставок із зворотними логістичними процесами, які варіюються від відновлення продукту, ремануфактурінга, розбирання та повторного використання окремих частин.

Застосування даних видів діяльності може бути реалізовано завдяки Індустрії 4.0, що сприяє більш ефективній координації матеріальних та інформаційних потоків. Ключовим завданням у цьому процесі $\epsilon$ ефективне генерування, збір, обробка та надання інформації про матеріальний зміст кожного продукту, його використання, місцезнаходження в системі відходів.

Ключові слова: реверсивні процеси, управління, сталий розвиток, циркулярна економіка.

\section{Література}

1. Razvitie i mezhdunarodnoe ekonomicheskoe sotrudnichestvo: Problemyi okruzhayuschey sredyi Www.un.org: [internet-portal]. 1987. URL: http://www.un.org/ru/ga/pdf/brundtland.pdf (viewed on: 2.04.2019).

2. Pialot O., Bisiaux J., Millet D. «Upgradable PSS»: Clarifying a new concept of sustainable consumption/production based on upgradablility // Journal of Cleaner Production. 2017. 4, 141. p. 538-550. doi: 10.1016/j.jclepro.2016.08.161

3. Our seas are being decreased, fish are dying - but humanity is threatened too // Www.theguardian.com: [Web-site]. 2015. URL: https://www.theguardian.com/environment/2015/sep/20/fish-are-dying-but-human-life-isthreatened-too (viewed on: 2.04.2019).

4. 4Ocean Team. How Much Trash Is In Our Ocean? // 4ocean.com: [Web-site]. 2017. URL: https://4ocean.com/blogs/blog/how-much-trash-is-in-our-ocean (дата звернення: 8.04.2019).

5. World Bank. Knowledge Papers: Urban Development Series. Chapter 3: Waste Generation // Worldbank.org: [Web-site]. 2016. URL: http://siteresources.worldbank.org/Resources/3363871334852610766/Chap3.pdf (viewed on: 07.04.2019).

6. Kumar S. Millennium Development Goals (MDGs) to Sustainable Development Goals (SDGs): Addressing Unfinished Agenda and Strengthening Sustainable Development and Partnership // Indian Journal of Community Medicine. 2016. Vol. 1, No. 41. P. 1-4. doi: 10.4103/0970-0218.170955

7. Geissdoerfer M. The Circular Economy - A new sustainability paradigm? // Journal of Cleaner Production. 2017. Vol. 4, No. 143. P. 757-768. doi: 10.1016/j.jclepro.2016.12.048

8. Pakhomova N.V., Richter K.K., Vetrova M.A. Circular Economy as Challenge to the Fourth Industrial Revolution // Інновації. 2017. Т. 7, вип. 225. С. 66-70.

9. Wupperinst.org: [internet-portal]. 2017. URL:

https://wupperinst.org/fa/redaktion/publications/In_Brief_2017-4_en.pdf. (viewed on: 5.04.2019).

10. Савіна І.В. Постіндустріальна економіка як економічна категорія, етапи становлення та рушійні сили // Вісн. Тернопільського нац. ун-ту. Економічні науки. Тернопіль: Тернопільський нац. ун-т, 2017.34 с.

11. Varian H. Microeconomic Analysis . N-Y: WW Norton, 1992. 559 p.

12. Шваб К. Четвертая промышленная революция: монография. М.: Эксмо, 2017. 138 с.

13. Пистер Е.И., Дайниченко А.В., Шестакова А.В. Четвертая промышленная революция: мегатренды / Инновационное развитие: потенциал науки и современного образования: сб. статей Междунар. научно-практ. конф., Пенза, 05 янв. 2018 г. Сб-П: «Наука и Просвещение», 2018. С.50-61

14. Рихтер К. Цифрова економіка - інновація 21 ст: виклики стійкого розвитку / Інноваціійний розвиток: потенціал науки та сучасної освіти: сб. статей Міжнар. наук.-практ. конф., Київ, 27лист. 2017р. К.: «Освіта 21 ст.», 2017. С.48-50

15. Індустрія 4.0: четверта промислова революція як стимул глобальної конкурентоспроможності. // Pmef-2017: [Веб-сайт]. 2017. URL: http://pmef-2017/articles/4277607 (viewed on: 5.04.2019).

16. Пахомова Н.В., Ветрова М.А. Переход к циркулярной экономике и замкнутым цепям поставок как фактор устойчивого развития // Вест. СПб ун-та. Сер. 5. Экономика. 2017. Т. 3, вып. 2. С. 244-267.

17. Macarthur E.O. Www.ellenmacarthurfoundation.org // Ellen MacArthur Foundation: Towards a Circular Economy: Business Rationale For An Accelerated Transition. Одеса, $2015 . \quad$ URL: https://www.ellenmacarthurfoundation.org/downloads/Foundation-9-Dec-2015.pdf (viewed on: 6.04.2019).

18. Battin D. Closed Loop Supply Chain (CLSC): Economics, Modeling, Management and Control // International Journal of Production Economics. 2017. Vol. 2, No. 183. P. 321-329. doi: 10.1016/j.ijpe.2016.11.020

19. Wilts H. The digital circular economy: can the digital transformation pave the way for resource-efficient materials cycles? / Wuppertal Institute. Berlin: Wuppertal Institute für Klima, Umwelt, Energie gGmbH, 2017. 120 p. doi: 10.19080/IJESNR.2017.07.555725

20. Korhonen J. Circular Economy: The Concept and its Limitations // Ecological Economics . 2018. Vol. 21, No. 143. P. 37-46. doi: 10.1016/j.ecolecon.2017.06.041

Стаття надійшла 15.04.2019 Стаття прийнята до друку 29.04.2019 Доступно в мережі Internet 5.07.2019

Цитування згідно ДСТУ 8302:2015

Sedikova I. Development of conceptual principles of the circular economy // Food Industry Economics. 2019. Vol.11, Issue 2. P. 4753. doi: 10.15673/fie.v11i2.1394

Cite as APA style citation

Sedikova I. (2019). Development of conceptual principles of the circular economy. Food Industry Economics, 11(2), 47-53. doi: 10.15673/fie.v11i2.1394 